GEOLOGICAL SURVEY CIRCULAR 136

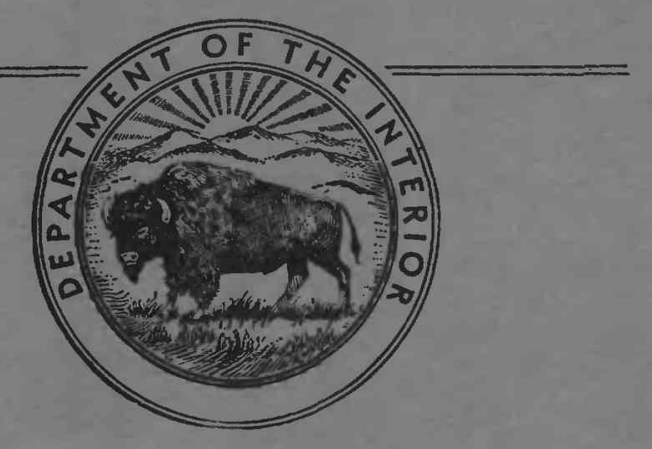

September 1951

\title{
GEOLOGY AT THE SITE OF A PROPOSED DAM AND RESERVOIR ON POWER CREEK NEAR CORDOVA, ALASKA
}

By

Don J. Miller 


\title{
UNITED STATES DEPARTMENT OF THE INTERIOR
}

\author{
Oscar L. Chapman, Secretary
}

GE O L O G I C A L S UR V EY

W. E. Wrather, Director

Washington, D. C.

Free on application to the Geological Survey, Washington 25, D. C. 


\title{
GEOLOGY AT THE SITE OF A PROPOSED DAM AND RESERVOIR ON POWER CREEK NEAR CORDOVA, ALASKA
}

\author{
CONTENTS
}

Page

Page

Summary and recommendations. . . 7

Introduction ........... . 1

Location, topography, and drainage. . 1

Water-power development and

previous investigations

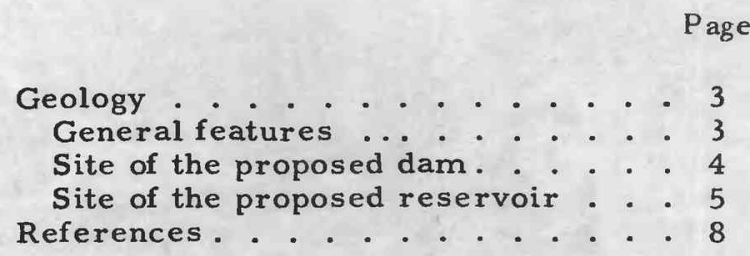

\section{ILLUSTR ATIONS}

Plate 1. Geologic map of the lower part of Power Creek Valley . . . Inside back cover

2. Map and section showing geology at proposed dam site on

Power Creek

Inside back cover

Figure 1. Aerial photograph of the lower part of Power Creek valley . . . . . 2

2. Ground view near center of landslide area. . . . . . . . . . . . 4

3. Ground view of proposed dam site on Power Creek . . . . . . . . . . 4

4. Aerial photograph of proposed dam site and adjacent area, Power

Creek. . . . . . . . . . . . . . . . . . . 6

\section{INTRODUCTION}

An investigation of the geology at the site of a proposed dam and reservoir on Power Creek near Cordova, Alaska, was made during the period June 22 to July 10, 1950, in accord with the request of B. Frank Heintzleman, Regional Forester, United States Forest Service, to the Conservation Division of the United States Geological Survey. In the course of the field work, which totaled about 6 days, geologic traverses were made in the lower part of Power Creek valley; horizontal and vertical control was obtained by plane-table methods, and panoramas were taken from several camera stations for the purpose of compiling geologic sketch maps of the lower part of Power Creek valley; and approximately 35 oblique aerial photographs were taken during a reconnaissance flight over Power Creek valley. Geologic features that might have a bearing on the proposed dam and reservoir were examined and discussed in the field with Arthur Johnson of the Conservation Division, Geological Survey, and with Harold Anderson, District Ranger of the Chugach National Forest. Mr. Johnson chartered the plane used in a reconnaissance flight over Power Creek valley, and accompanied the writer on traverses to the proposed dam site and to a camera station overlooking the valley. Mr. Anderson accompanied the writer on a traverse to the proposed dam site, and assisted in making a stadia-photo traverse of the canyon at the dam site. Officials of the Town of Cordova furnished a truck for the writer's use.

The principal results of the investigation were summarized in a preliminary report without illustrations (Miller, 1950), pending completion of the maps and other illustrations incorporated in the present report.

\section{LOCATION, TOPOGRAPHY, AND DRAINAGE}

Power Creek rises from a small glacier in the Chugach Mountains at a point about 13 miles northeast of Cordova, flows southwestward through a narrow valley for a distance of approximately 7 miles, and enters Eyak Lake near Mile 6 on the road leading from Cordova to Power Creek. (See insert map, pl. 1.) The altitude of the creek at its source at the foot of the glacier is about 1,000 feet; the altitude at the mouth of the creek is 8 feet. In the upper $21 / 2$ miles of its course Power Creek flows is a shallow canyon cut in unconsolidated glacial and alluvial deposits. In the stretch from 2 to $41 / 2$ miles above the mouth of the valley the creek meanders from one side of the valley to the other on a flood plain of unconsolidated mud, sand, and gravel, from a quarter of a mile to half a mile in width. At a point about 2 miles above the mouth of the valley the creek swings to the southeast side of the valley and flows in a steepwalled canyon, 200 to 450 feet deep, cut in part in bedrock. Less than half a mile from the mouth of the valley the creek emerges from the canyon and flows across a delta formed by filling in of the northeast end of an arm of Eyak Lake. 




Figure 1.--Aerial photograph of the lower part of Power Creek valley showing the fanlike ridge extending across the valley. The approximate extent of the material interpreted as landslide debris is indicated by the dashed line, the approximate location of the maximum flow line of the proposed reservoir by the dotted lines.

The average width of Power Creek valley, measured from the crests of the ridges forming the valley walls, is about $13 / 4$ miles. The valley walls are steep, rising abruptly from the valley floor to a general altitude of 2,000 to 3,500 feet and a maximum altitude (near the head of the valley) of more than 4,000 feet.

The valley of Power Creek exhibits the U-shaped profile and flat floor that is typical of glacial-scoured and partially re-filled valleys in the region, except in the lower 2 miles. In this stretch the even fall of the valley floor is interrupted by a broad fan-like ridge that extends nearly across the valley from the northwest side, rising to a maximum altitude of about 1,100 feet. (See pl. I and fig. 1.) This feature is responsible for the canyon and the concentrated fall in the lower part of Power Creek valley.

The entire valley of Power Creek lies within the Chugach National Forest.

\section{WATER-POWER DEVELOPMENT AND PREVIOUS INVESTIGATIONS}

The falls on the lower part of Power Creek early attracted attention to the possibilities for power development. Water rights were held on the creek for many years by one or more persons, and at one time a tunnel was started for diverting water through a ridge to a proposed power-house site below Ohman Falls. A Geological Survey party made a brief investigation of the water-power possibilities of Power Creek in 1913 (Ellsworth, 1915, pp. 69-71), and private companies or individuals have made more or less detailed investigations, including stream surveys and collection of stream flow data, from time to time (Renner, 1950 personal communication). A gaging station established by the Geological Survey near the mouth of Power Creek in August 1947 has been in nearly continuous ope ration since that date. In 1948 a Geological Survey party in the charge of Arthur Johnson mapped the lower 6 miles (stream length 8 miles) of Power Creek and obtained other data required for a brief analysis of the water-

power possibilities of the creek. (Johnson, 1949). The published map of Power Creek shows the topography of the lower part of Power Creek and of the basin of the proposed reservoir in considerable detail, and also shows some topographic features that are mentioned in this report but are not shown on plate 1. 
The general geology of a large area including Power Creek valley is described in a report by Grant and Higgins (1910). The report on water-power possibilities by Ellsworth and Davenport (1915, p. 70) includes a brief description of the mining characteristics of the rock in the tunnel on Power.Creek. A Bureau of Reclamation report (1948, pp. 160-161) on the waterpower resources of Alaska includes a brief description of Power Creek based in part on a reconnaissance examination of the dam site area in 1948 by geologists A. E. Jaskar and W. H. Irwin of the Bureau of Reclamation. Additional information on the results of this investigation was gained through discussion with Mr. Jaskar, and from an unpublished report (Irwin, 1948) in the files of the Bureau of Reclamation office in Juneau, Alaska.

\section{GEOLOGY}

\section{General features}

The bedrock exposed in both walls of Power Creek valley and in the upper part of the canyon along lower Power Creek consists of folded and slightly metamorphosed bedded rocks, mainly gray to black argillaceous sediments (argillite and slaty argillite); hard, poorly sorted gray sandstone (graywacke); and green, purple, and red lava, tuff, and breccia (volcanic rocks). The average strike of the bedded rocks is about $\mathrm{N}$. $60^{\circ} \mathrm{E}$., at a small angle to the trend of Power Creek valley. Although many local variations in dip were noted, the regional dip in the lower part of Power Creek valley is to the northwest in the northwest valley wall and to the southeast in the southeast valley wall. The rocks probably are tightly folded here, as elsewhere in the Prince William Sound region, and thus at many places are overturned.

The bedrock exposed in an area extending about half a mile along the northwest side of Power Creek, including part of the northwest wall of the canyon at the proposed dam site, is more intensely deformed and fractured than elsewhere in the lower part of Power Creek valley. This area is believed to lie in or just northwest of a fault zone. The southeastern margin of the fault zone follows approximately the course of Power Creek in the upper part of the canyon, and passes through the proposed dam site. The alltitude of the bedded rocks in the area of more intense deformation is variable and at many places is discordant, in both strike and dip, with the attitude of the less deformed rocks to the southeast.

The fanlike ridge extending across the lower part of Power Creek valley from the northwest side to the previously described area of deformed bedrock is believed by the writer to be in large part a slide of loose rock (a landslide) that came from the northwest valley wall, partially filling the glaciated valley and forcing Power Creek to cut through a bedrock spur along the southeast side of the valley. The following features support this interpretation: (1) The northwest valley wall, adjacent to and above the fan-like ridge, shows a relatively smooth, sloping surface bounded on the northeast and southwest by steep scarps, suggestive of the source of the debris in the valley and the surface along which movement occurred (pl. 1 and fig. 1); (2) The surface of the fan-like ridge shows many terraces and elongate depressions which approximately parallel the valley wall or the outer margin of the ridge (pl. 1 and fig. 1); (3) Loose, angular blocks of rock are exposed on the surface of the fan-like ridge at many places (fig.2). Blocks of rock as much as 40 feet in largest dimension were observed in ground traverses on the ridge, and other blocks estimated to be at least 100 feet in largest dimension were observed from the air; (4) Drainage on the fan-like ridge, about 2 square miles in area, is almost entirely underground in spite of the heavy precipitation. No permanent streams flow across the feature and none of the larger depressions, which are as much as 100 feet in depth and several hundred feet in largest diameter, contain water.

The landslide may have resulted from oversteepening of the northwest wall of Power Creek valley by glacial scour. That the slide occurred before the ice had entirely melted from the part of the valley now occupied by the fan-like ridge is suggested by the presence on the ridge of conical depressions resembling moulins, and by the great distance through which the debris at the outer margin of the ridge apparently has moved. The debris could be expected to move through a considerable distance from the source if it slid out into an ice-filled valley, and melting of the ice beneath the slide debris could have caused the conical depressions.

The writer's geologic examination was concentrated mainly in the part of the canyon selected by Johnson (1949, pp. 29-31) as the most favorable site, topographically, for a dam, and to the adjacent part of the ridge that would form the downstream wall of the proposed reservoir. At the time of the examination the canyon at the proposed dam site still was filled with snow to a maximum depth of about 70 feet (fig. 3). Although the snow prevented examination of part of the canyon at the dam site, it is believed unlikely that it concealed any critical geologic features or that the conclusions expressed in this report would be altered if the canyon were 


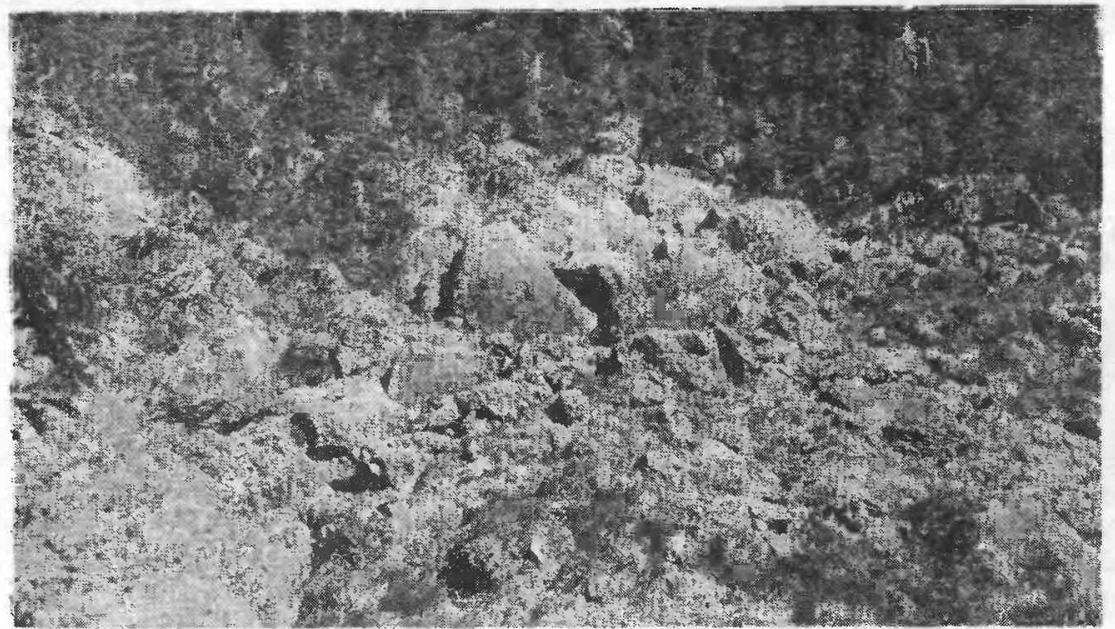

Figure 2.--Ground view near center of landslide area, showing blocky character of the surface. The exposed part of the large block of graywacke near the center of the view is about 15 feet high.



Figure 3.--Ground view of the proposed dam site on Power Creek. Dashed line indicates approximate location of the section $A-A^{\prime}$, plate 2 .

examined when all of the snow is melted. The canyon at the proposed dam site ordinarily is free of snow by late July or early August.

\section{Site of the proposed dam}

Plate 2 shows the geology and topography in the vicinity of the proposed dam site and along a section in the narrowest part of the canyon. The proposed dam site also is shown in a photograph taken downstream from a point at the head of the canyon (fig. 3 ), and in two aerial photographs (fig. 1 and fig. 4). 
The bedrock exposed in the southeast wall, the floor, and a small part of the northwest wall of the canyon at the proposed dam site consists of evenly bedded, relatively slightly deformed and fractured argillite and graywacke which lies southeast of a fault zone (pl. 2). The strike of the beds ranges from N. $55^{\circ}$ E. to N. $85^{\circ} \mathrm{E}$. and the dip ranges from $40^{\circ}$ to $75^{\circ} \mathrm{SE}$. The dip decreases gradually from northwest to southeast across the canyon. It is about $75^{\circ} \mathrm{SE}$. in the northwest wall of the canyon near the level of Power Creek, about $60^{\circ} \mathrm{SE}$. in the bed of Pcwer Creek, and about $400 \mathrm{SE}$. in the southeast canyon wall at a height of 100 feet above Power Creek. Sedimentary features in several oriented rock specimens of the evenly bedded argillitegraywacke sequence at the proposed dam site suggest that the sequence is overturned to the northwest. The sequence of evenly bedded argillite and graywacke continues up the southeast valley wall above the proposed dam site to the top of the ridge, with approximately the same range in strike and apparent dip as in the floor and lower part of the southeast wall of the canyon. A few hundred feet downstream from the dam site the evenly bedded argillite-graywacke sequence is in depositional contact with a sequence of volcanic rocks, including massive beds of lava, tuff, and volcanic breccia. The volcanic sequence does not crop out along Power Creek immediately northwest of the fault.

Except for a narrow band of relatively slightly deformed and fractured argillite and graywacke that forms the lower canyon wall at the narrowest part, the bedrock exposed in scattered outcrops in the northwest wall of the canyon at the proposed dam site consists of intensely deformed and fractured argillite, slaty argillite, and graywacke. These outcrops lie in or northwest cf the fault zone along Power Creek. The attitude of the bedding varies widely within outcrops, and from one outcrop to another.

The evenly bedded argillite-graywacke. sequence that would form the southeast (left) abut ment, the foundation, and the lower part of the northwest (right) abutment appears to be sufficieatly strong to support a gravity-type dam, either rigid or flexible, and sufficiently tight to prevent excessive leakage around the dam. Both the argillite and graywacke are hard, little altered by weathering, and show slight to moderate fracturing. The freshest exposures, in the stream bed and the canyon walls immediately adjacent to it, show few fractures, indicating that the open fractures are largely a surface weathering phenomenon and that relatively tight bedruck would be encountered within a few feet of the surface. The scattered outcrops in the upper part of the northwest wall of the canyon, which would form part of the right abutment of the dam site, on the other hand, indicate that the bedrock there is intensely fractured. If, as suggested in this report, the fracturing is due mainly to faulting rather than to surface weathering, little improvement in the strength and tightness of the bedrock could be expected within feasible depth.

Although some of the argillite beds contain small concretions of impure limestone, and some of the argillite and graywacke contains a small amount of calcium carbonate as a cementing material, none of the bedrock at the proposed dam site seems to be sufficiently calcareous to cause either leakage around the abutments of a dam or weakening of the foundation due to solution of calcium carbonate.

Bedrock is exposed continuously in the floor and lower part of the canyon walls in the vicinity of the section $A-A^{\prime}(p l, 2)$ and probably is not covered by more than a few feet of loose rock and soil anywhere in the southeast wall of the canyon at the proposed dam site. The mantle of loose rock and soil is generally thicker and more continuous in the upper part of the northwest wall of the canyon. Natural and artificial exposures of the bedrock-mantle profile suggest that the maximum thickness of the mantle in this part of the proposed dam site probably is less than 20 feet and possibly is less than 10 feet.

\section{Site of the proposed reservoir}

Johnson (1949, p. 35) concluded that an altitude of 550 feet probably would be the maximum feasible reservoir height obtainable by impounding water behind a dam at the site described in the preceeding section. He assumed a maximum flow line of 540 feet altitude for calculating the power that could be developed by diverting water from the reservoir through a short tunnel in the bedrock ridge northwest of the dam site. The approximate trace of the 540-foot level on the valley walls around the lower part of the proposed reservoir is shown on figures 1 and 4 . A reservoir having a surface altitude of 540 feet would be less than 20 feet below the rim of a drained depression on the upstream side of the ridge extending across Power Creek valley, at a point about 1,500 feet northwest of the dam site (see published map of Power Creek). At the narrowest place the ridge that would form the downstream wall of the reservoir is about 300 feet wide at the 540-foot contour. The reservoir. would extend a little more than 3 miles upvalley from the proposed dam site. 


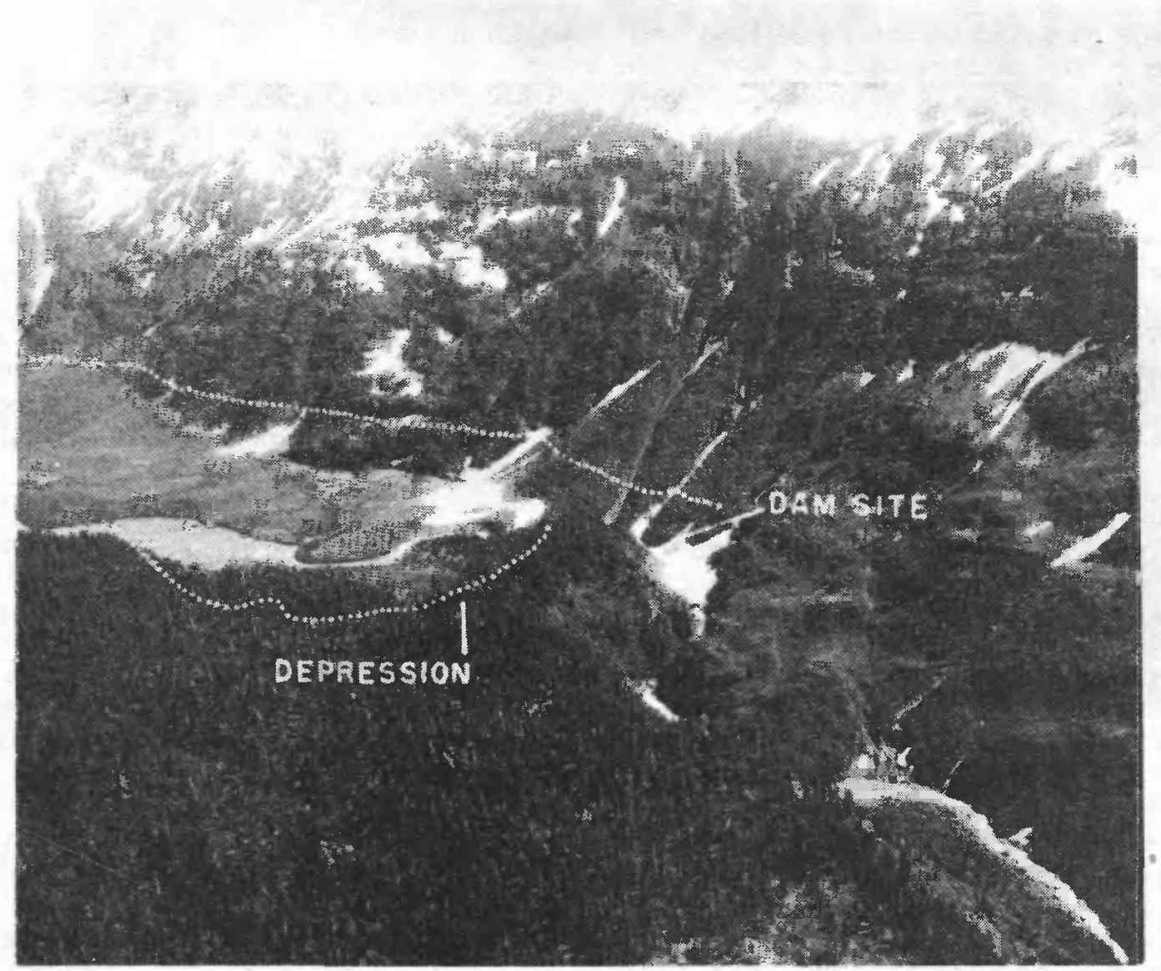

Figure 4. --Aerial photograph of the proposed dam site and adjacent area, Power Creek. Dotted lines indicate approximate location of maximum flow line of proposed reservoir. Note blocky character of landslide surface in lower left corner.

The floor of the proposed reservoir (below the thick fill of unconsolidated deposits) and the wall of the proposed reservoir from the dam site along the southeast side of the valley, around the head, and down the southwest side to the landslide (pl. 1) consists of bedrock that almost certainly is sufficiently tight and insoluble to insure negligible leakage. The northwest wall of the proposed reservoir for a distance of about $11 / 2 \mathrm{miles}$ above the dam site, however, consists of relatively pervious materials.

The part of the ridge extending from the proposed dam site northwestward about 1,000 feet on the upstream side and about 1, 500 feet on the downstream side is underlain by moderately to intensely deformed bedrock like that exposed in the upper part of the northwest canyon wall at the dam site. The width of the bedrock ridge at the 540 -foot contour ranges from about 300 to 600 feet. Outcrops along the west and northwest side of Power Creek on the downstream side of the ridge and at the head of the canyon are fractured argillite, slaty argillite, and graywacke. Much of the argillite shows poorly developed to fairly well developed slaty cleavage that intersects the bedding at angles varying from a few degrees to nearly $90^{\circ}$. Numerous springs, some with a substantial flow of water, issue from bedrock on the downstream side of the ridge from the creek level up to an altitude of about 350 feet. These indicate that water is leaking through the bedrock ridge from the upstream side. Additional information on the character of the rock forming the ridge is given by Ellsworth and Davenport (1915, p. 70), who described the rock penetrated by a tunnel driven on the downstream side of the ridge as follows:

"The formation was of soft rock which could be broken down without the assistance of explosives. The rock disintegrated rapidly on exposure to air and it was found necessary to timber the tunnel as work progressed.'

The portal of this tunnel is reported to be about 200 feet west of the observation point at Ohman Falls (bench mark 407) and about 20 feet above the trail (see Johnson, 1949, published map of Power Creek). The portal is said to be slumped shut and in recent years has become so well concealed that no evidence of it could be found even with the aid of a map showing its approximate location (Renner, 1950, personal communication). 
In the interval from about 1,000 to 6,000 feet above the dam site the northwest wall of the proposed reservoir is formed of coarse, angular, loose blocks of bedrock, interpreted in this report as landslide debris (pl. 1). If the interpretation of the origin of the fan-like ridge, as outlined on pages 10 and 12 , is correct, then the loose debris may extend to a depth of several hundred feet and may also form part of the floor of the reservoir, beneath the cover of alluvium. The blocky, loose character of the surface, the lack of surface drainage, and the presence of drained depressions all attest to the porous character of the fan-like ridge. The most critical locality probably is in the vicinity of the depression approximately 1,500 feet northwest of the proposed dam site, near the margin of the area mapped as landslide debris. (Johnson, 1949 , p. 11; published map of Power Creek). This depression, which is formed in loose angular blocks of rock, is about 300 feet across and 75 feet deep. The upstream rim of the depression at one point is less than 20 feet above the maximum flow line of the proposed reservoir, and the bottom of the depression is about 40 feet lower than the maximum flow line. Water could be heard running beneath the blocks in the bottom of the depression when it was examined by Johnson in 1948 and by the writer in 1950.

The trunks of mature spruce and hemlock trees growing on parts of the fan-like ridge are straight, indicating that the mass has been stable for a long time and is not likely to show renewed movement.

\section{SUMMARY AND RECOMMENDATIONS}

The bedrock exposed in Power Creek valley at the site of the proposed dam and reservoir consists of folded and slightly metamorphosed bedded rocks of.sedimentary and volcanic origin, mainly argillite, graywacke, lava, tuff, and volcanic breccia. The regional strike of the bedding is nearly parallel to the trend of Power Creek valley; the dip is variable, but generally steep. The bedrock at most places is only slightly deformed and fractured, but in a fault zone that passes through the proposed dam site it is intensely deformed and fractured. A fanlike ridge, believed to be landslide, extends nearly across Power Creek valley from the northwest and is responsible for the concentrated fall along the lower part of Power Creek.

The bedrock that is exposed or within a few feet of the surface in the southeast wall, the floor, and the lower part of the northwest wall of the canyon at the proposed dam site appears to be sufficiently strong to provide an adequate foundation for a gravity-type dam, either rigid or flexible, and sufficiently water-tight and insoluble to prevent excessive leakage around the dam.

The upper part of the northwest wall of the canyon at the proposed dam site, however, apparently consists of intensely deformed and fractured bedrock, covered in part by a mantle of loose rock and soil possibly as much as $20 \mathrm{feet}$ thick at some places. If, as seems likely, the excessive fracturing of the bedrock here is due to faulting rather than to surface weathering, little improvement in the strength and tightness of the bedrock could be expected within feasible depth.

The northwest wall and the adjacent floor of the proposed reservoir for a distance of $11 / 2$ miles above the dam site consists in part of intensely deformed and fractured bedrock and in part of loose, angular blocks which are believed to be landslide debris. The lack of surface drainage, the presence of springs, and other features of this area indicate that subsurface leakage is substantial under the present conditions and might prevent storage to the desired level in the proposed reservoir. The bedrock that would form the wall and floor (beneath alluvium) of the remainder of the proposed reservoir almost certainly is sufficiently tight and insoluble to insure negligible leakage.

The bedrock ridge northwest of the dam site appears to be a feasible site for a tunnel to divert water from the proposed reservoir to a power house. Judging from the surface exposures, and the description of a previous attempt to drive a tunnel at this locality, the rock would be easily broken and removed but would require timbering or other support. The tunnel almost certainly would have to be lined with an impervious material if the tunnel walls are to be in contact with running water.

The writer's geologic study of the lower part of Power Creek valley raises doubt that the ridge which would form the upper part of the northwest (right) abutment of the proposed dam and part of the wall and floor of the proposed reservoir is strong enough to provide an adequate foundation for the proposed dam, or is sufficiently water-tight to prevent excessive leakage from the proposed reservoir. More exact information on the water-tightness, strength, and solubility of the materials forming this ridge, which factors will have a bearing on the cost, 
design, and ultimate feasibility of the proposed dam and reservoir, should be obtained at an early stage in the planning. More detailed investigations along the following lines are suggested:

1. Information on the water-tightness of the part of the reservoir wall formed of landslide debris could be obtained at the narrowest, and therefore most critical, point by pumping water into the drained depression about 1,500 feet northwest of the proposed dam site.

2. Information on the water-tightness of the part of the reservoir wall formed by the bedrock ridge northwest of the proposed dam site could be obtained by observing the rate of leakage of water from pits or drill holes sınk in the bedrock, and possibly also by draining the small pond north of the ridge and observing the effect on the springs issuing along Power Creek south of the ridge.

3. Information on the strength and solubility of the bedrock at the proposed dam site could be obtained by suitable laboratory tests, and information on the water-tightness of the bedrock could be obtained by observing the rate of leakage of water from pits or drill holes sunk into the bedrock. Shallow pits or drill holes will provide suitable rock samples and an adequate test of the water-tightness of the bedrock in the southeast wall, floor, and lower part of the northwest wall of the canyon at the proposed dam site, but at least one fairly deep pit or drill hole may be required to adequately test the upper part of the northwest canyon wall.

\section{REFERENCES CITED}

Ellsworth, C. E., and Davenport, R. W., 1915, A water-power reconnaissance in southcentral Alaska: U.S. Geol. Survey Water-Supply Paper 372, pp. 69-71.

Grant, U.S., and Higgins, D.F., 1910, Reconnaissance of the geology and mineral resources of Prince William Sound, Alaska: U.S. Geol. Survey Bull. 443.

Irwin, W. H., 1948, Power Creek dam site--Cordova area (manuscript report in files of U.S. Bur. Reclamation).

Johnson, Arthur, 1949, Preliminary report on water-power resources of Power Creek near Cordova, Alaska: U.S. Geol. Survey mimeographed report, 37 pp., April. (Maps and profile published later in 1949 by U.S. Geol. Survey as Plan and profile of Power Creek near Cordova, Alaska.)

Miller, D. J., 1950, Preliminary report on the geology of a proposed dam site on Power Creek near Cordova, Alaska, (manuscript in files of U.S. Forest Service), Sept.

Renner, Ralph, 1950, Alaska Public Utilities, Cordova, Alaska, personal communication, July 1 .

U. S. Bur. Reclamation, 1948, A reconnaissance report on the potential development of water resources in Alaska: Dept: Interior, pp. 160-161. 


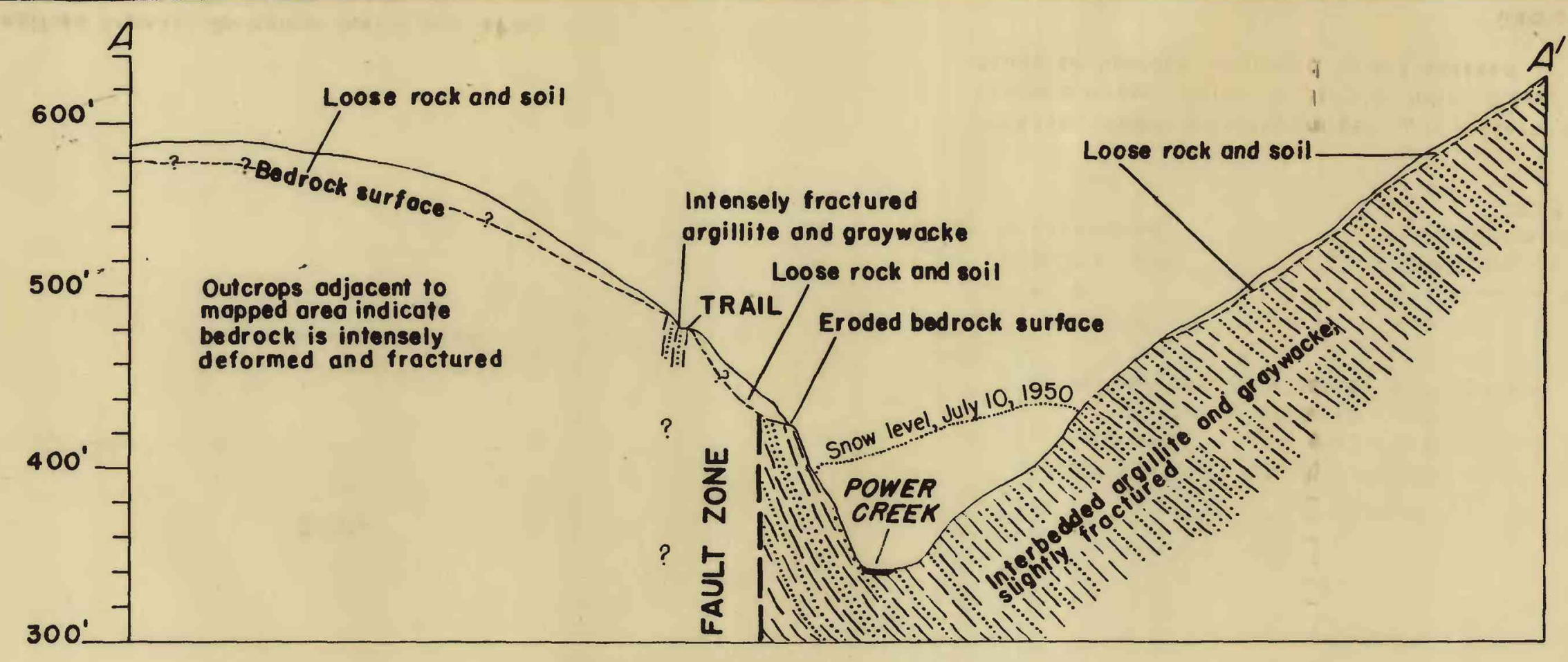

Horizonfal and vertical scales are equal SECTION ALONG THE LINE A-A'
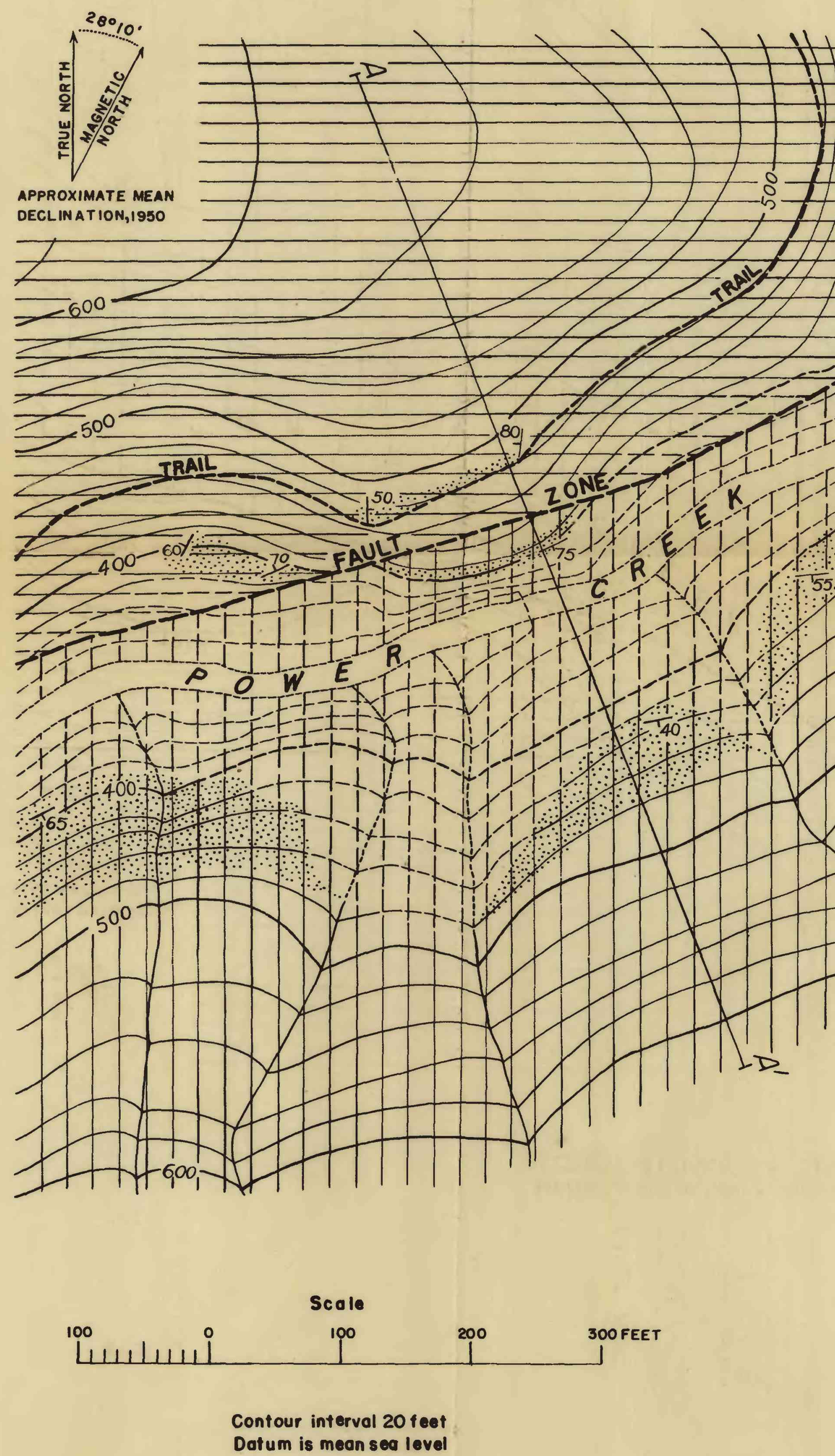

\section{EXPLANATION}

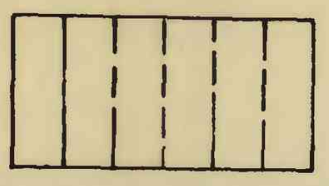

Slightly froctured argillite and groywocke; exposed, or within a fow feet of the surface Potiern dashed in area covered by snow

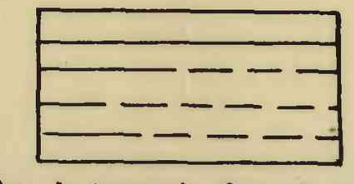

Moderately (?) to Intensely fractured argillite slaty argillite, and graywacke; largely covered by loose rock and soil Pattern dashed in orea covered by snow

\section{Approximate location of southe astern margin of} foult zone 